\title{
POTENSI CENDAWAN Beauveria bassiana (BALSAMO) VUILLEMIN ISOLAT BOGOR TERHADAP MORTALITAS LARVA PENGGEREK BATANG SENGON (Xystrocera festiva) PASCOE DI LABORATORIUM
}

\author{
Potency of Beauveria bassiana (Balsamo) Vuillemin Bogor Isolate Fungi on \\ the Mortality of Xystrocera festiva Pascoe in Laboratory \\ Wida Darwiati ${ }^{1}$ dan/and Suhaeriyah ${ }^{2}$ \\ ${ }^{1}$ Pusat Litbang Hutan Tanaman, Kampus Balitbang Kehutanan \\ Jl. Gunung Batu No.5, Bogor, Telp. (0251) 8631238, Fax. (0251) 7520005 \\ ${ }^{2}$ Universitas Padjadjaran \\ Jl. Raya Jatinangor Km 21, Bandung
}

Naskah masuk: 4 Februari 2008 ; Naskah diterima: 4 Februari 2009

\begin{abstract}
Xystrocera festiva (Coleoptera : Cerambicydae) is one of the highly potential pest attacking sengon (Paraserianthes falcataria L. Fosberg) plantation in field. One of the environmental friendly techniques to control this pest is by using entomophatogenical fungi, Beauveria bassiana (Balsamo) Vuillemin. This experiment was aimed to determining the efficacy of spore density level of B. bassiana Bogor Isolate against $X$. festiva population on sengon. The experiment had been carried out since July until August 2006 at the laboratory of Entomology and Phytophatology, Department of Pest and Plant Diseases Science, Faculty of Agriculture, Universitas Padjadjaran, Jatinangor, West Java. The experiment was arranged in a randomized complete design consisted of six treatments and four replications. The results showed that each of the spore density level was able to control X. festiva larvae. The most effective concentration was $10^{11}$ spore/ml which caused $100 \%$ mortality of X. festiva larvae at seventh days. However the mortality caused by spore density of $10^{8} \mathrm{spore} / \mathrm{ml} 84.93 \%$ was not significantly different.
\end{abstract}

Key words: Sengon, Beauveria bassiana, Xystrocera festiva, laboratory

\begin{abstract}
ABSTRAK
Hama yang potensial menyerang tegakan sengon (Paraserianthes falcataria L.Fosberg) adalah hama penggerek batang Xystrocera festiva Pascoe (Coleoptera : Cerambicydae), dan salah satu teknik pengendalian hama yang ramah lingkungan adalah dengan menggunakan cendawan entomopatogen Beauveria bassiana (Balsamo) Vuillemin. Penelitian bertujuan untuk menentukan tingkat kerapatan spora cendawan entomopatogen $B$. bassiana isolat Bogor yang dapat menyebabkan mortalitas tinggi terhadap larva X. festiva. Penelitian dilakukan pada bulan Juli sampai dengan Agustus 2006 di Laboratorium Fitopatologi dan Entomologi Jurusan Hama dan Penyakit Tumbuhan Fakultas Pertanian, Universitas Padjadjaran, Jatinangor, Jawa Barat. Penelitian ini memakai Rancangan Acak Lengkap (RAL) yang terdiri dari enam perlakuan dan empat ulangan. Hasil penelitian menunjukkan bahwa setiap perlakuan spora cendawan B. bassiana mampu mengendalikan larva X. festiva. Hasil uji statistik menunjukkan bahwa antar perlakuan tidak berbeda nyata. Kerapatan spora $10^{8}$ spora/ml merupakan perlakuan yang menyebabkan mortalitas larva $X$. festiva terendah sebesar $84,93 \%$ sedangkan perlakuan kerapatan spora $10^{11}$ spora/ml menyebabkan mortalitas tertinggi sebesar $100 \%$ pada hari ke tujuh.
\end{abstract}

Kata kunci : Sengon, Beauveria bassiana, Xystrocera festiva, laboratorium 


\section{PENDAHULUAN}

Tanaman sengon merupakan salah satu jenis komoditi yang paling banyak ditanam oleh masyarakat khususnya petani hutan rakyat di Jawa. Meningkatnya minat untuk menanam sengon disebabkan oleh beberapa faktor antara lain adanya nilai pasar yang cukup baik, masa tumbuh yang cepat dengan daur 7-8 tahun, riap volume yang umumnya dapat mencapai $20-50 \mathrm{~m}^{3} / \mathrm{tahun} / \mathrm{ha}$ dan kayunya yang memiliki kualitas yang baik untuk pulp dan kertas. Namun dalam perkembangannya tanaman ini mengalami kerusakan berat akibat serangan hama penggerek batang Xystrocera festiva Pascoe (Coleoptera : Cerambycidae).

Pengendalian secara kimiawi dapat dilakukan dengan menyemprotkan insektisida. Untuk meminimalisir dampak negatif seperti pencemaran lingkungan, perlu upaya alternatif pengendalian lain yang sesuai dengan konsep Pengendalian Hama Terpadu (PHT). Pada konsep PHT, pestisida masih dapat digunakan untuk mengendalikan hama, tetapi dibatasi hanya pada saat serangan hama tidak dapat ditoleransi lagi atau telah melewati batas ambang ekonomi. Salah satu alternatif pengendalian adalah pemanfaatan cendawan yaitu Beauveria bassiana (Balsamo) Vuillemin (Anonim, 2006b).

Keunggulan penggunaan cendawan $B$. bassiana antara lain selektif terhadap serangga sasaran sehingga tidak membahayakan serangga non-sasaran seperti predator dan parasitoid; tidak meninggalkan residu beracun pada hasil pertanian dalam tanah maupun pada aliran air alami; tidak menyebabkan fitotoksik pada tanaman; serta mudah diperbanyak dengan teknik sederhana di laboratorium (Anonim, 2006a). Oleh karena itu terkait dengan pemanfaatan cendawan B. bassiana isolat Bogor yang berasal dari Nilapavarta lugens terhadap $X$. festiva, perlu dilakukan pengujian nilai kerapatan spora cendawan $B$. bassiana untuk mengetahui kerapatan spora cendawan $B$. bassiana yang dapat menyebabkan mortalitas larva $X$. festiva.

\section{A. Xystrocera festiva}

$\boldsymbol{X}$. festiva Pascoe adalah jenis serangga hama yang merusak kulit pohon dan memanfaatkan floem atau bagian kulit sebelah dalam dari pohon inang sebagai sumber makanan dan habitat untuk melangsungkan siklus hidupnya, mampu mematikan pohon, serta menurunkan kualitas dan volume kayu pertukangan. Apabila kerusakan pada pohon sampai melingkari batang, maka aliran zat makanan dari daun ke akar akan terganggu dan pohon akan mati. Hama ini sering masuk menggerek ke dalam kayu untuk berkepompong. Akibatnya batang pohon berlubang-lubang dan akan menurunkan kualitas kayunya (Husaeni, 2001).

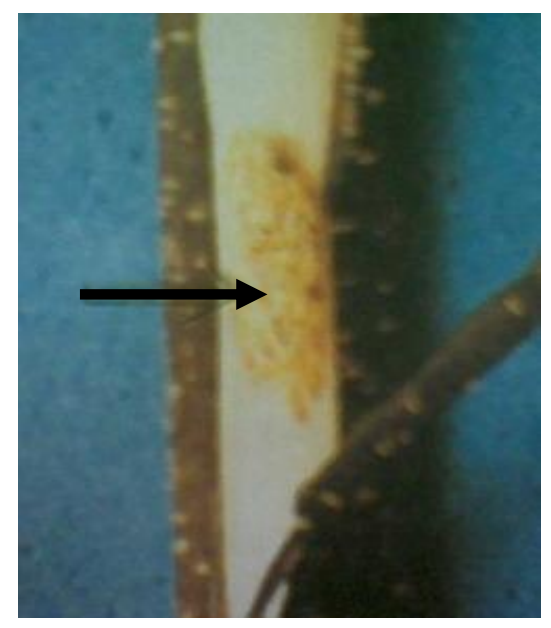

Gambar (Figure) 1. Sekelompok telur X. festiva (eggs of X. festiva) (Sumber/source: Hardi, 1998) 
Imago (kumbang) X. festiva berwarna kuning kemerahan, warna hijau kebiruan pada pinggir luar elytra dan sisi prothoraks. Antena imago jantan panjangnya 2 kali panjang badan. Panjang badan serangga dewasa $30-38 \mathrm{~mm}$ dan lebar $7-9 \mathrm{~mm}$. Lama stadium imago jantan $2-13$ hari, imago betina $2-7$ hari. Telur berbentuk oval dengan ukuran $2 \times 1 \mathrm{~mm}$, berwarna hijau kekuningan sampai kuning, berdekatan dengan zat perekat yang tidak berwarna.

Telur diletakkan pada bekas-bekas cabang, atau luka lubang secara berkelompok. Seekor imago dapat meletakkan telurnya sampai 400 butir, stadium telur 15 - 20 hari. Larva yang keluar dari telur mulai menggerek kulit bagian dalam dan kayu muda secara bergerombol ke arah bawah. Larva berwarna kekuningan tak bertungkai jelas. Larva yang baru menetas $2 \times 1 \mathrm{~mm}$, larva dewasa berukuran $50 \times 9 \mathrm{~mm}$. Bagian pohon yang digerek akan mengeluarkan cairan sehingga terlihat berwarna hitam atau coklat. Bubuk gerek tertinggal dalam lubang gerek dan sebagian keluar dari lubang-lubang kulit atau kulit yang pecah. Lama stadium larva $5-6$ bulan. Semakin tua umur tegakan biasanya persentase serangan lebih tinggi. Menurut Suharti dkk. (1994) kandungan lignin pada sengon muda umur dua tahun sebesar $25,41 \%$, umur empat tahun sebesar $21,82 \%$. Larva yang akan masuk stadium pupa menyebar ke dalam batang pohon dan membelok ke arah atas. Panjang lubang gerek dapat mencapai 20 $\mathrm{cm}$. Larva akan berkepompong di ujung lubang gerek dengan kepala di bawah. Pupa berwarna putih kekuningan dengan ukuran $30 \times 30 \mathrm{~cm}$, stadium pupa 15 - 21 hari. Imago yang dihasilkan dari pupa akan keluar melalui lubang gerek kemudian menggigit kulit pohon yang menghalanginya. Imago sering tidak segera keluar dari lubang gerek tetapi beberapa saat tinggal di dalam. Siklus hidup serangga ini berlangsung $6-8$ bulan (Husaeni, 2001).

\section{B. Beauveria bassiana (Balsamo) Vuillemin}

Beauveria bassiana termasuk kelas Deuteromycetes (Moniliales; Moniliaceae), merupakan salah satu cendawan yang sudah dikenal sebagai cendawan entomopatogen. Peranan cendawan $B$. bassiana yaitu memproduksi toksin beauvericin yang berfungsi melemahkan sistem kekebalan tubuh serangga. Selain itu menghasilkan toksin bassianolit, isorolit, dan asam oksalat yang dapat meningkatkan $\mathrm{pH}$ darah, penggumpalan darah, terhentinya peredaran darah serangga, kerusakan rongga tubuh, sistem saraf, serta sistem pencernaan yang mengakibatkan kematian serangga (Wiryadiputra, 1994).

Cendawan B. bassiana mempunyai miselia yang bersekat dan berwarna putih dengan ukuran diameter 2-4 $\mu \mathrm{m}$. Hifa fertil bercabang, tersusun melingkar (verticillate) dan biasanya menggelembung atau menebal. Spora aseksual (konidia) menempel pada ujung sisi konidiofor atau cabang-cabangnya (Gambar 2). Konidia bersel satu, berbentuk oval agak bulat (globose) sampai bulat telur (obovate), berwarna hialin dengan diameter 2-3 $\mu \mathrm{m}$. Konidiofor berbentuk zig-zag dan berkelompok yang merupakan ciri khas dari genus Beauveria, sedang miselium di bawahnya menggelembung. Pertumbuhan cendawan $B$. bassiana cukup cepat, diameter kumpulan hifanya mencapai $1-3 \mathrm{~cm}$ jika diinkubasi pada suhu $25^{\circ} \mathrm{C}$ selama 7 hari pada media PDA (Potato Dextrose Agar). Koloni cendawan $B$. bassiana berwarna putih dan selanjutnya akan berubah kekuningan dengan bertambahnya umur, tekstur hifanya seperti kapas atau tepung (Wiryadipura, 1994).

B. bassiana dapat menginfeksi inangnya melalui permukaan kulit, saluran makanan atau pernapasan. Keberhasilan infeksi tersebut dipengaruhi oleh faktor lingkungan seperti suhu dan kelembaban relatif (Junianto \& Sukamto, 1995). Cendawan B. bassiana mengadakan penetrasi pada tubuh serangga melalui kulit pada bagian di antara kapsul kepala dan thoraks serta di antara ruas-ruas tubuh. Mekanisme penetrasi dimulai dengan pertumbuhan spora pada kutikula, selanjutnya hifa mengeluarkan enzim yang membantu menguraikan kutikula serangga. 


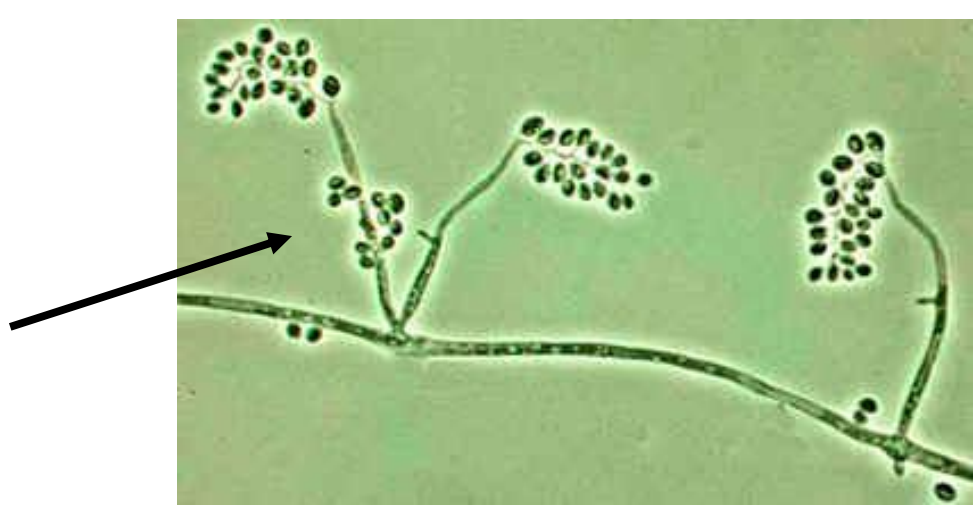

Gambar (Figure) 2. Spora B. bassiana (spore of B. bassiana) (Sumber/source: Anonim, 2006a)

\section{II . BAHAN DAN METODE}

\section{A. Tempat dan Waktu}

Penelitian dilakukan di Laboratorium Fitopatologi dan Entomologi, Jurusan Hama dan Penyakit Tumbuhan, Fakultas Pertanian, Universitas Padjadjaran, Jatinangor. Percobaan dilaksanakan mulai bulan Juli sampai Agustus 2006.

\section{B. Bahan dan Alat}

Bahan-bahan yang digunakan dalam percobaan ini adalah larva X. festiva, B. bassiana isolat Bogor yang berasal dari Nilapavarta lugens, media PDA (Potato Dextrose Agar), biji jagung pecah, akuades, alkohol, insektisida berbahan aktif dimetoat, dan serbuk kayu sengon.

Alat-alat yang digunakan adalah autoclave, laminair flow, inkubator, mikroskop, haemocytometer, magnetic stirrer, petri dish, gelas objek, ose, toples, kuas halus, kain kasa, beaker glass, gelas ukur, kertas saring, plastik, karet, dan timbangan.

\section{Metode Percobaan}

Penelitian menggunakan metode Rancangan Acak Lengkap (RAL), yang terdiri dari 6 perlakuan dan 4 ulangan. Perlakuan yang diuji adalah aplikasi spora dalam formulasi air dengan berbagai kerapatan sebagai berikut :

$\mathrm{A}=10^{11} \mathrm{spora} / \mathrm{ml}$ air

$\mathrm{B}=10^{10} \mathrm{spora} / \mathrm{ml}$ air

$\mathrm{C}=10^{9} \mathrm{spora} / \mathrm{ml}$ air

$\mathrm{D}=10^{8} \mathrm{spora} / \mathrm{ml}$ air

$\mathrm{E}=$ Kontrol (hanya diberi serbuk kayu sengon sebagai makanan)

$\mathrm{F}$ = Insektisida sebagai pembanding $(1 \mathrm{ml} /$ liter air $)$

Data hasil pengamatan dianalisis dengan menggunakan uji jarak berganda Duncan.

\section{Tahap Persiapan Penelitian}

\section{D.1. Perbanyakan isolat B. bassiana pada media PDA}

Isolat B. bassiana diperoleh dari koleksi laboratorium Balai Penelitian Tanaman Rempah dan Aromatik (BALITTRO). Isolat yang digunakan berasal dari $N$. lugens dan dibiakkan dalam media PDA. Setelah cendawan B. bassiana yang dimurnikan tumbuh, kemudian perbanyakan massal 
cendawan $B$. bassiana dalam media jagung. Selanjutnya dimasukkan ke dalam kantong plastik tahan panas sebanyak $100 \mathrm{~g}$ (Gambar 3) dan disterilkan dalam autoclave dengan tekanan 1 atm selama 30 menit pada suhu $121^{\circ}$. Jika media jagung telah dingin maka proses inokulasi dari media PDA ke media jagung dapat dilakukan, yaitu pada suhu $24-25^{\circ} \mathrm{C}$. Setelah dua minggu, sumber inokulum dapat digunakan (Silvia, 2006).
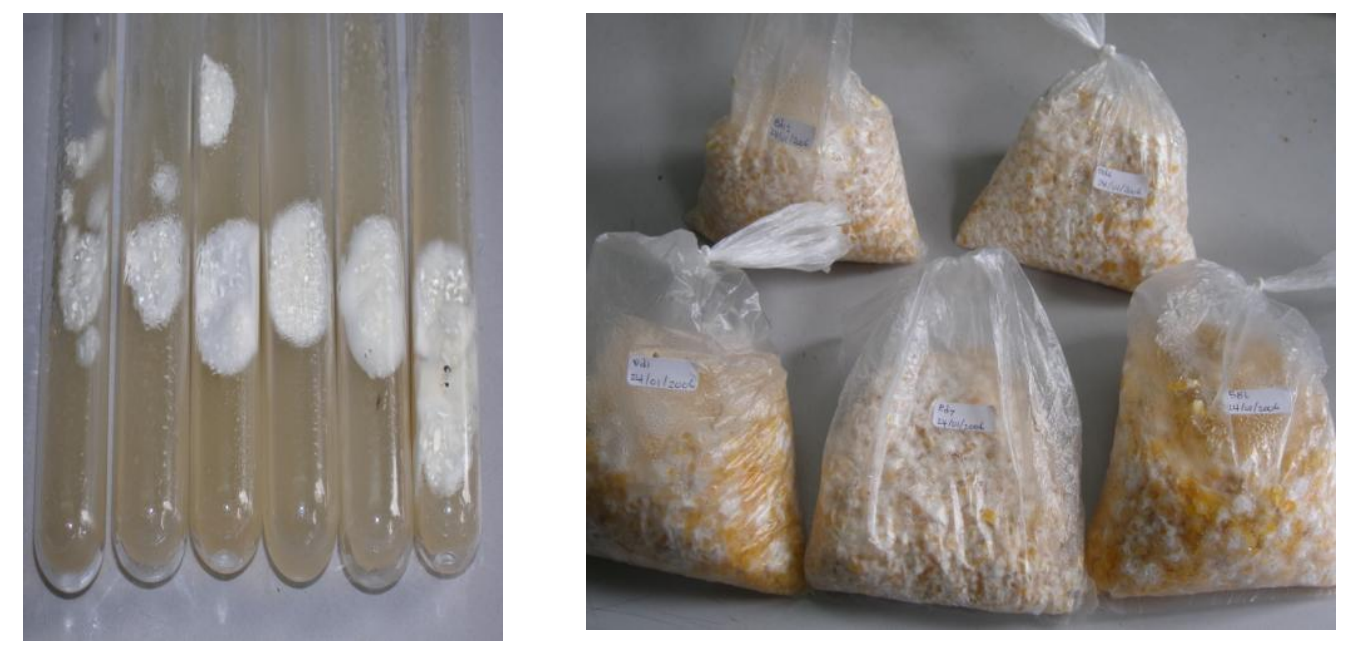

Gambar (Figure) 3. Perbanyakan B. bassiana pada media PDA dan pada media jagung (Sumber/source: Wahyono, 2006)

\section{D.2. Pembuatan Suspensi Spora Beauveria bassiana}

Untuk mendapatkan suspensi spora yang sesuai dengan perlakuan, maka spora B. bassiana yang berasal dari biakan cendawan B. bassiana sebanyak $10 \mathrm{~g}$ dimasukkan ke dalam $100 \mathrm{ml}$ akuades, ditempatkan dalam beaker glass, lalu dikocok dengan magnetic stirrer. Selanjutnya dilakukan pengenceran untuk mempermudah penghitungan spora. Pengenceran dilakukan dengan cara menghomogenkan $1 \mathrm{ml}$ suspensi spora yang telah didapat dengan $9 \mathrm{ml}$ akuades. Dari larutan tersebut dipipet sebanyak 1 tetes ke dalam salah satu counting chamber dari haemocytometer, kemudian dihitung spora pada setiap kotak dengan menggunakan mikroskop.

\section{D.3. Penyediaan Larva $X$. festiva}

Larva X. festiva dapat diperoleh di sekitar Bogor. Larva-larva tersebut kemudian ditempatkan pada wadah plastik dan diberi makan serbuk kayu sengon.

\section{E. Pelaksanaan Penelitian}

\section{E.1. Uji Patogenitas Isolat B. bassiana}

Larva $X$. festiva instar dua dimasukkan ke dalam stoples yang telah berisi serbuk kayu sengon masing-masing stoples berisi 20 ekor larva. Suspensi spora cendawan B. bassiana tersebut diinokulasikan pada larva $X$. festiva sesuai perlakuan dengan cara diteteskan sebanyak $10 \mathrm{cc}$. Pada perlakuan kontrol hanya dimasukkan serbuk kayu sengon dan serangga uji. Stoples seluruhnya ditutup dengan kain kasa (Gambar 4).

Setiap larva yang mati diinkubasikan ke dalam petri dish berisi kapas lembab untuk memicu pertumbuhan hifa cendawan. Hifa putih yang tumbuh menyelubungi larva dikulturkan dalam media PDA untuk memastikan bahwa jenis cendawan tersebut adalah cendawan B. bassiana. 


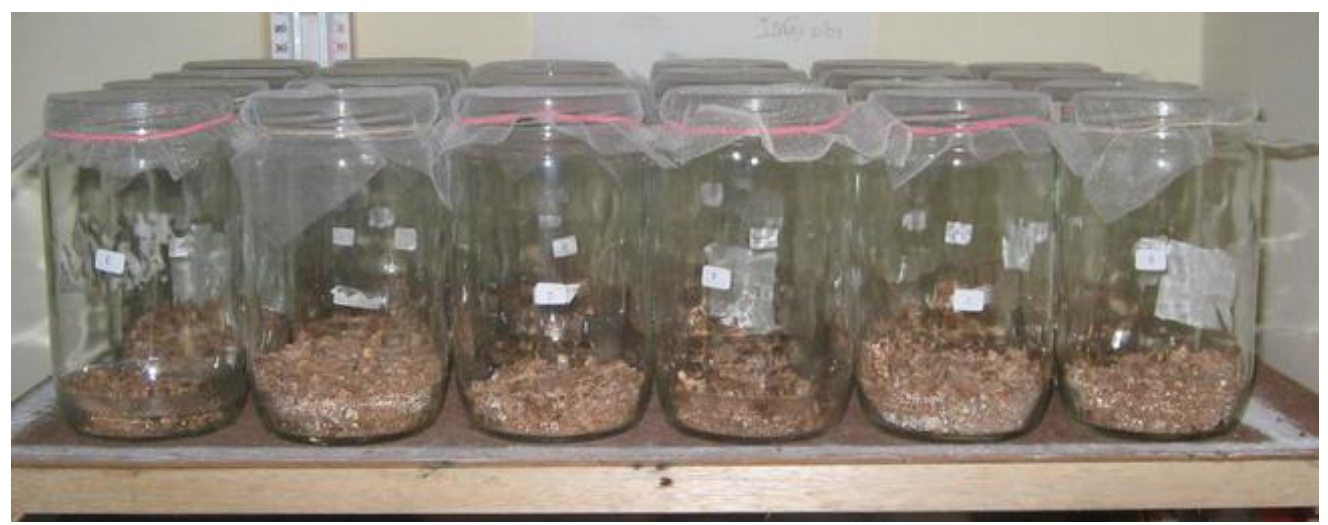

Gambar (Figure) 4. Larva X. festiva yang diaplikasikan B. bassiana dan serbuk kayu dalam stoples (Larvae of X. festiva applied to B. bassiana and saw dust in a jar)

\section{HASIL DAN PEMBAHASAN}

\section{A. Mortalitas Larva X. festiva}

Hasil penelitian di laboratorium menunjukkan bahwa tingkat mortalitas larva $X$. festiva pada semua perlakuan sangat tinggi. Tingkat mortalitas tercepat terjadi pada perlakuan A yaitu dengan kerapatan $10^{11}$ spora/ml mampu menyebabkan kematian pada hari kedua sedangkan perlakuan B, C, D kematian dicapai pada hari keempat dan hari keenam (Gambar 5). Hal ini sesuai dengan pernyataan Prayogo dkk. (2004) yang menyatakan bahwa semakin tinggi kerapatan spora cendawan entomopatogen, maka makin tinggi dan cepat terjadi mortalitas serangga karena spora cendawan memproduksi toksin yang berfungsi melemahkan sistem kekebalan tubuh serangga.

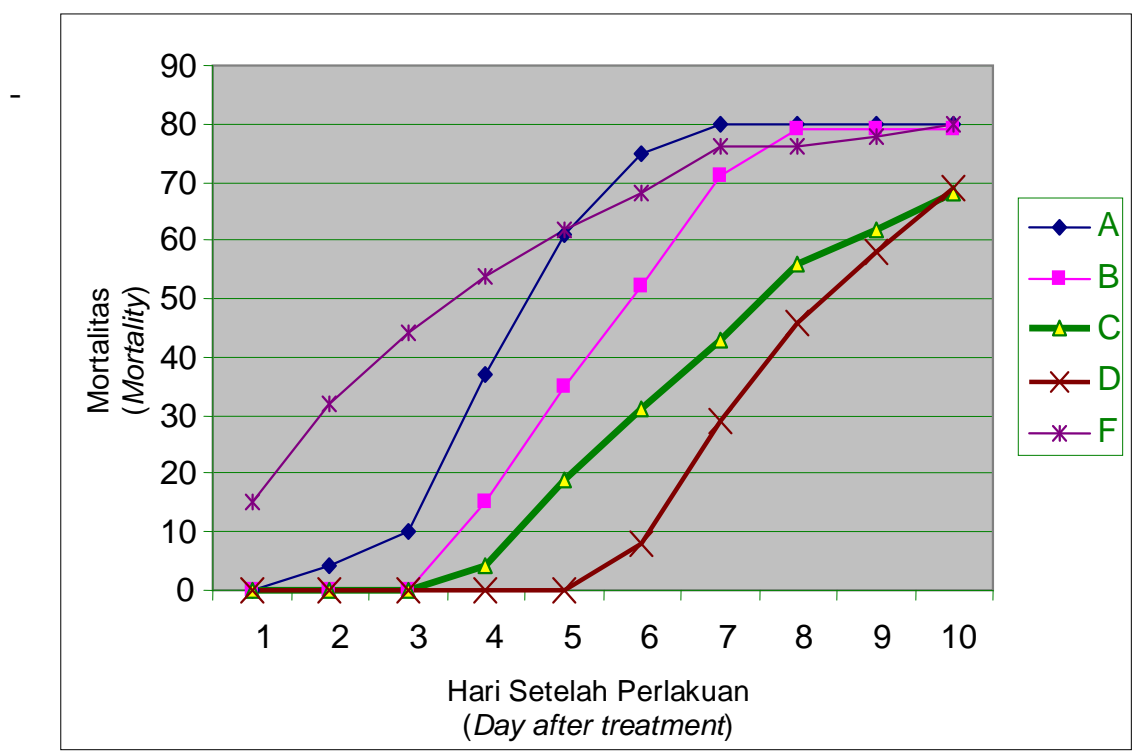

Gambar (Figure)7. Grafik mortalitas X. festiva akibat infeksi cendawan B. bassiana (Graph of the mortality of $\mathrm{X}$. festiva infected by the fungi of $\mathrm{B}$. bassiana)

Keterangan (remarks): $\mathrm{A}=10^{11} \mathrm{spora} / \mathrm{ml}$ air (spore $/ \mathrm{ml}$ water $) ; \mathrm{B}=10^{10} \mathrm{spora} / \mathrm{ml}$ air $; \mathrm{C}=10^{9} \mathrm{spora} / \mathrm{ml}$ air; $\mathrm{D}=$ $10^{8}$ spora/ml air $\mathrm{E}=$ Kontrol (control); $\mathrm{F}=$ Insektisida sebagai pembanding/insecticide as comparison ( $1 \mathrm{ml} / /$ liter air) 
Tabel (Table)1. Rata-rata mortalitas X. festiva yang terinfeksi oleh jamur B. bassiana dengan berbagai kerapatan spora pada hari ketujuh (Average mortality of $\mathrm{X}$. festiva infected by $\mathrm{B}$. bassiana fungi with various spora density on the seventh day)

\begin{tabular}{|l|c|}
\hline \multicolumn{1}{|c|}{ Perlakuan (Treatment) } & $\begin{array}{c}\text { Mortalitas larva X. festiva (\%) } \\
\text { (Mortality of X. festiva larvae) }\end{array}$ \\
\hline A. Kerapatan spora $10^{11}$ spora/ml air & $100.00 \mathrm{~b}$ \\
\hline B. Kerapatan spora $10^{10}$ spora/ml air & $98.63 \mathrm{~b}$ \\
\hline C. Kerapatan spora $10^{9} \mathrm{spora} / \mathrm{ml}$ air & $86.30 \mathrm{~b}$ \\
\hline D. Kerapatan spora $10^{8} \mathrm{spora} / \mathrm{ml}$ air & $84.93 \mathrm{~b}$ \\
\hline E. Kontrol & $0.00 \mathrm{a}$ \\
\hline F. Insektisida Pembanding & $100.00 \mathrm{~b}$ \\
\hline
\end{tabular}

Keterangan (remarks): Angka rata-rata yang diikuti oleh huruf yang sama tidak berbeda nyata menurut uji Duncan pada taraf $5 \%$ (Average numbers/values followed by the same lettters are not significantly different according to Duncan's test on 5\% level)

Dari Tabel 1 terlihat bahwa cendawan B. bassiana isolat Bogor dapat menyebabkan mortalitas $X$. festiva sebesar $100 \%$. Dari tabel tersebut juga diketahui bahwa antar perlakuan A, B, C, D, dan F tidak berbeda nyata, tetapi berbeda nyata dengan kontrol, dan pada perlakuan A dan $\mathrm{F}$ cenderung menunjukkan mortalitas yang tinggi. Adanya mortalitas pada kontrol dapat dipastikan bukan akibat cendawan B. bassiana karena pada tubuh larva yang mati (mortalitas $0 \%$ pada kontrol) tidak terselubungi oleh hifa putih sebagai indikator terinfeksi cendawan $B$. bassiana.

Mekanisme infeksi diawali dengan kontak antara propagul cendawan B. bassiana dengan tubuh larva. Propagul cendawan $B$. bassiana berupa konidia karena merupakan cendawan yang berkembang biak secara tidak sempurna. Tahap kedua adalah proses penempelan dan perkecambahan propagul cendawan $B$. bassiana pada integumen larva, kelembaban udara yang tinggi dan bahkan kadang-kadang air diperlukan untuk perkecambahan propagul cendawan. Pada tahap ini, cendawan dapat memanfaatkan senyawa-senyawa yang terdapat pada integumen larva (Prayogo dkk., 2004). Perkecambahan propagul cendawan yang tinggi memperbesar peluang cendawan untuk menyebabkan mortalitas pada serangga hama. Perkecambahan propagul cendawan merupakan awal dari tahapan pertumbuhan cendawan entomopatogen sebelum melakukan penetrasi ke integumen serangga (Junianto \& Sulistyowati, 1994). Proses perkecambahan propagul cendawan diawali dengan membengkaknya dinding spora. Selanjutnya tabung kecambah muncul pada satu sisi dinding spora berupa tonjolan. Tabung kecambah tumbuh dengan cepat membentuk hifa yang bercabang-cabang. Setelah perkecambahan berlangsung beberapa jam, dapat muncul tabung kecambah baru pada sisi lain sehingga terbentuk dua tabung kecambah (Junianto dkk., 2000).

Selanjutnya cendawan $B$. bassiana mengadakan penetrasi ke tubuh larva melalui kulit pada bagian lekukan antara kepala dan thoraks serta di antara ruas-ruas tubuh. Dalam melakukan penetrasi menembus integumen larva, cendawan membentuk tabung kecambah (apresorium). Penembusan dilakukan secara mekanis atau kimiawi dengan mengeluarkan enzim dan toksin. Setelah itu, tahap destruksi dan terbentuknya blastospora yang kemudian beredar ke dalam hemolimfa dan membentuk hifa sekunder untuk menyerang jaringan lainnya (Prayogo dkk., 2004). Cendawan B. bassiana menghasilkan toksin yang mengakibatkan paralisis pada larva dan imago Coleoptera diantaranya dalam bentuk beauvericine yang berfungsi melemahkan sistem kekebalan tubuh serangga, beauverolide, bassianolide, isorolide dan zat warna serta asam oksalat yang dapat meningkatkan $\mathrm{pH}$ darah, penggumpalan darah, terhentinya peredaran darah, kerusakan rongga tubuh serangga, kerusakan sistem saraf, dan sistem pencernaan yang mengakibatkan mortalitas serangga (Wiryadiputra, 1994). Serangga yang terinfeksi jamur entomopatogen dapat berubah warna dan kadang-kadang terdapat bercak hitam pada kutikula. Bercak hitam terjadi karena ada jaringan tubuh larva yang mati di sekitar tempat penetrasi jamur. Pada infeksi awal, larva menunjukkan gejala sakit yaitu tidak mau makan, lemah dan kurang aktif. Jika pertumbuhan cendawan terjadi di dalam tubuh larva, maka cairan dalam tubuh larva 
akan habis digunakan oleh cendawan, sehingga larva mati dengan tubuh mengeras seperti mumi (Meldy, 1995). Miselia cendawan menembus keluar tubuh larva pada bagian yang paling mudah terserang yaitu di antara ruas-ruas tubuh dan alat mulut. Pada waktu bagian ruas tubuh larva ditumbuhi miselia jamur, larva sudah tidak bisa bergerak dan miselia terus berkembang sampai seluruh tubuh terbungkus warna putih (Gambar 8). Selanjutnya, spora memproduksi antimikroba oosporein yang dapat mencegah pertumbuhan bakteri dan pembusukan pada bangkai serangga. Apabila keadaan kurang mendukung, perkembangan cendawan hanya berlangsung di dalam tubuh serangga tanpa ke luar menembus integumen. Dalam hal ini cendawan membentuk struktur khusus untuk dapat bertahan, yaitu arthrospora (Meldy dkk., 1995).

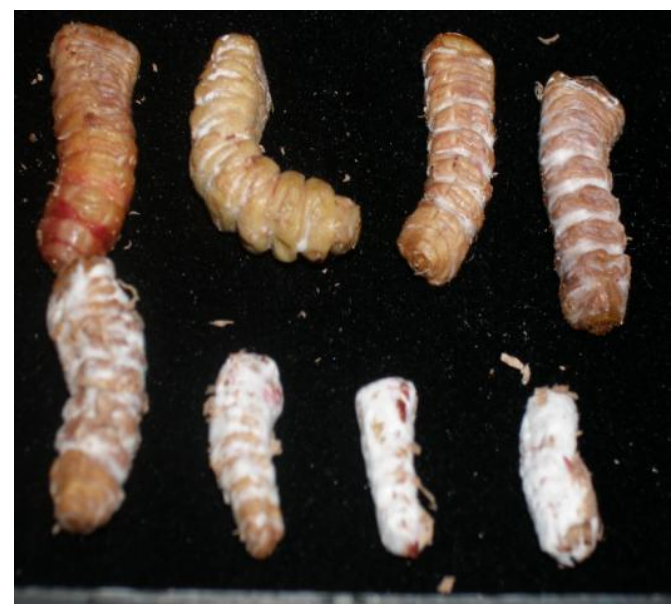

Gambar (Figure) 8. Larva yang terinfeksi B. bassiana (Larvae infected by B. bassiana) (Sumber/source : Wahyono, 2006)

Perlakuan dengan insektisida dapat menyebabkan mortalitas larva sebesar $100 \%$. Hal ini dikarenakan insektisida ini bersifat racun kontak sehingga dapat mematikan larva dengan cepat. Insektisida mampu mematikan larva sejak hari pertama setelah perlakuan (Gambar 7). Berdasarkan hasil uji statistik, perlakuan A, B, C, dan D tidak berbeda nyata dengan pembanding. Namun disisi lain telah diketahui bahwa insektisida mempunyai efek utama yang tidak bagus antara lain tanaman yang disemprot insektisida akan tumbuh lebih cepat dengan tunas-tunas baru yang lebih sukulen dan disukai hama tersebut. Selain itu, penggunaan insektisida yang tidak tepat akan membunuh predator dan parasitoid hama tersebut. Oleh karena itu, penggunaan insektisida perlu dilakukan secara tepat, baik jenis, dosis, alat semprot, dan waktu penyemprotannya (Prayogo dkk., 2004).

Menurut Prayogo dkk. (2004) penggunaan insektisida hendaknya menjadi alternatif terakhir dan dilakukan bila ambang kendali telah dilampaui. Pengendalian secara kimiawi dalam bidang kehutanan selain mahal juga secara teknis sukar dilaksanakan dan tidak begitu efektif seperti untuk hama pertanian. Hal ini sangat berbeda dengan cendawan entomopatogen yang tidak menyebabkan resistensi hama karena spora cendawan merupakan makhluk hidup yang mematikan serangga untuk mendapatkan nutrisi dan akan selalu berusaha menginfeksi serangga sebagai inang sumber nutrisi dan media perkembangannya di alam, namun pemanfaatan cendawan entomopatogen pada dasarnya harus mempertimbangkan faktor-faktor yang mempengaruhinya, yaitu faktor internal dan eksternal.

Beragamnya jumlah larva yang mati pada perlakuan, berhubungan dengan proses kerja cendawan dan perkembangan cendawan yang dipengaruhi oleh keadaan cuaca setempat, terutama iklim mikro tempat serangga tersebut berada (Sukasman, 1996). Suhu dan kelembaban relatif (RH) adalah faktor fisik yang sangat besar pengaruhnya terhadap perkembangan B. bassiana. Pada suhu atau RH tertentu proses perkecambahan, pertumbuhan dan sporulasi sangat baik tetapi dapat pula menjadi terhambat. Suhu optimum untuk pertumbuhan yaitu $25-30^{\circ} \mathrm{C}$ dan kelembaban relatif $100 \%$ (Junianto \& Sukamto, 1995). 


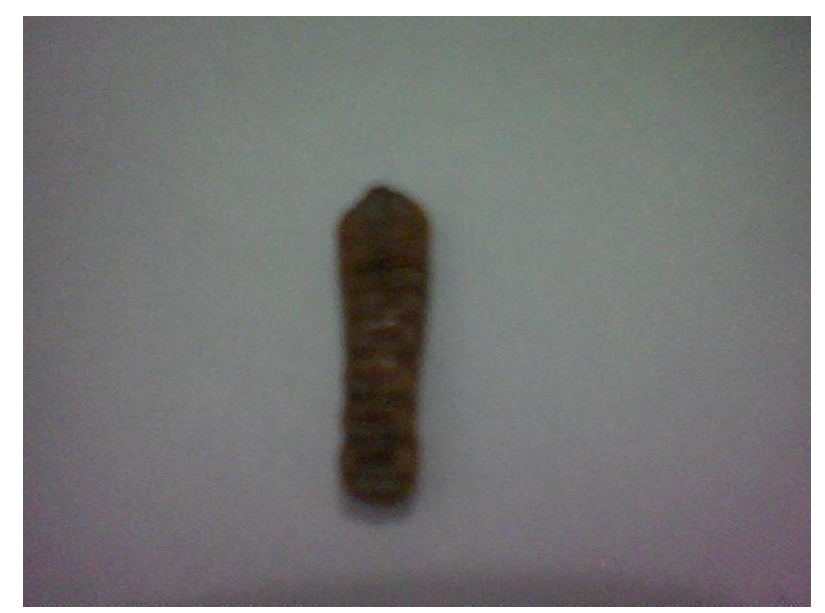

Gambar (Figure) 9. Larva yang terinfeksi bakteri (larvae infected by the bacteria)

\section{KESIMPULAN DAN SARAN}

\section{A. Kesimpulan}

Cendawan Beauveria bassiana isolat Bogor yang berasal dari Nilapavarta lugens dapat menginfeksi larva Xystrocera festiva pada skala laboratorium. Tingkat mortalitas semua perlakuan sangat tinggi dan diantara kerapatan tidak berbeda nyata, namun pada perlakuan kerapatan spora $10^{11}$ dan perlakuan insektisida sebagai pembanding dapat menyebabkan mortalitas tercepat pada hari kedua, dan pada hari ke tujuh mortalitas dicapai $100 \%$.

\section{B. Saran}

Cendawan Beauveria bassiana memiliki potensi yang baik untuk terus dikembangkan dalam rangka menunjang pengendalian hama baik secara parsial maupun secara terpadu untuk masa yang akan datang. Percobaan potensi cendawan B. bassiana isolat Bogor terhadap mortalitas larva Xystrocera festiva baru dilakukan di laboratorium, sehingga perlu dilakukan percobaan di lapangan untuk mengetahui pengaruhnya pada aplikasi tanaman sengon.

\section{DAFTAR PUSTAKA}

Anonim. 2006a. Beauveria bassiana. http://en.wikipedia.org. Diakses 27 Januari 2006.

Anonim. 2006b. Insektisida Alami Patogen Serangga Jamur Beauveria bassiana Pengendali Walang Sangit. http://www.pemda-diy.go.id. Diakses 20 Mei 2006.

Hardi, T.W. 1998. Mengenal Lebih Dekat Hama Boktor, Xystrocera festiva. Pusat Litbang Hutan dan Konservasi Alam, Bogor.

Husaeni, E. 2001. Hama Hutan Tanaman. Fakultas Kehutanan IPB, Bogor.

Junianto, Y. D. and E. Sulistyowati. 1994. Virulence of Several Beauveria bassiana Bals. Vuill. Isolates on Coffee Berry Borer (Hypothenemus hampei Ferr.) under Various Relative Humidities. Pelita Perkebunan. Vol. 10. No. 2. Hlm.: 81-86. 
Junianto, Y.D. dan S. Sukamto. 1995. Pengaruh Suhu dan Kelembaban Relatif terhadap Perkecambahan, Pertumbuhan dan Sporulasi beberapa Isolat Beauveria bassiana. Pelita Perkebunan, Pusat Penelitian Tanaman Kopi dan Kakao. Jember. 11(2): 64-75.

Junianto, Y. D., H. Semangun, A. Harsojo dan E. S. Rahayu. 2000. Viabilitas dan Virulensi Blastopora Beauveria bassiana (Bals.) Vuill. Kering-Beku pada beberapa Suhu Simpan. Pelita Perkebunan. Vol. 16. No. 1. Hlm. 30-41

Natawiria, D. 1973. Hama dan Penyakit Albizia falcataria \{L.\} Fosberg. Lembaga Penelitian Hutan. Bogor

Meldy L.A. Hosang, J.C. Alouw and H. Novarianto. 1995. Biological control of Brontispa longissima (Gestro) in Indonesia. Indonesian Coconut and Other Palm Research Institute, Manado.

Prayogo, Y., W. Tengkano dan Marwoto 2004. Pemanfaatan cendawan entomopatogen Metarhizium anisopliae (Metsch.) Sorokin untuk mengendalikan hama ulat grayak Spodoptera litura pada kedelai. Jurnal Litbang Pertanian, 24(1), Malang.

Silvia, E. 2006. Beauveria bassiana sebagai Pengendali Hama Tanaman. Warta Penelitian dan Pengembangan Pertanian. Cianjur. Vol. 28(1).

Sukasman. 1996. Entomopatogen sebagai Insektisida. Prosiding Seminar Sehari Alternatif Pengendalian Hama Teh secara Hayati. Pusat Penelitian Teh dan Kakao. Hlm. 32-39.

Wahyono, T.E. 2004. Pemanfaatan Cendawan Patogen Serangga sebagai Pengendali Serangga Hama Tanaman. Balai Penelitian Tanaman Rempah dan Aromatik. Bogor

Wiryadiputra, S. 1994. Prospek dan Kendala Pengembangan Cendawan Entomopatogenik Beauveria bassiana untuk Pengendalian Hayati Hama Penggerek Buah Kopi, Hypothenemus hampei. Pelita Perkebunan. 3: 92-93. 


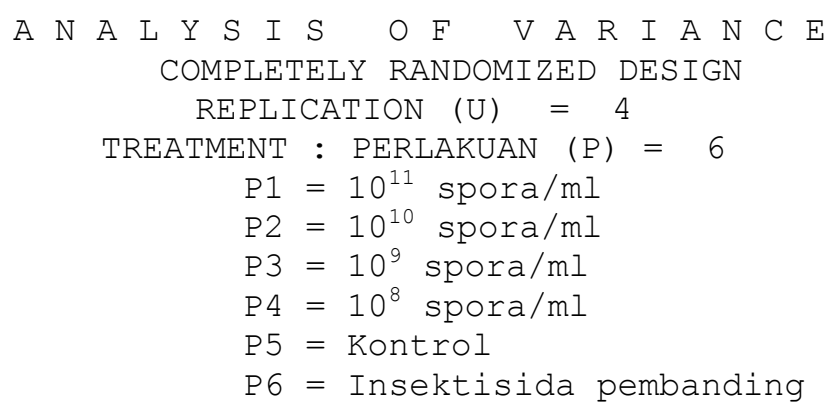

MORTALITAS LARVA (\%)

$\begin{array}{llll}\text { U1 } & \text { U2 } & \text { U3 }\end{array}$

$\begin{array}{lrrrr}\text { P1 } & 20.0000 & 20.0000 & 20.0000 & 20.0000 \\ \text { P2 } & 19.0000 & 20.0000 & 20.0000 & 20.0000 \\ \text { P3 } & 15.0000 & 18.0000 & 18.0000 & 19.0000 \\ \text { P4 } & 17.0000 & 16.0000 & 20.0000 & 16.0000 \\ \text { P5 } & 2.0000 & 2.0000 & 3.0000 & 0.0000 \\ \text { P6 } & 20.0000 & 20.0000 & 20.0000 & 20.0000 \\ & & & & \\ \text { REP TOTALS } & 93.0000 & 96.0000 & 101.0000 & 95.0000\end{array}$

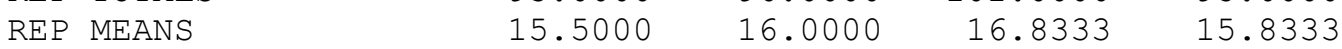

$\begin{array}{rrrr}\text { MORTALITAS LARVA } & \left(\frac{\circ}{\circ}\right) \text { IN LOG SCALE } & \\ \text { U1 } & \text { U2 } & \text { U3 } & \text { U4 } \\ & & & \\ 26.5650 & 26.5650 & 26.5650 & 26.5650 \\ 25.8419 & 26.5650 & 26.5650 & 26.5650 \\ 22.7864 & 25.1040 & 25.1040 & 25.8419 \\ 24.3500 & 23.5781 & 26.5650 & 23.5781 \\ 8.1301 & 8.1301 & 9.9742 & 0.0000 \\ 26.5650 & 26.5650 & 26.5650 & 26.5650 \\ & & & \\ 134.2385 & 136.5072 & 141.3382 & 129.1151 \\ 22.3731 & 22.7512 & 23.5564 & 21.5192\end{array}$

1

Arcsine (Sqr $(\mathrm{X} / 100))$ 
ANALYSIS OF VARIANCE FOR MORTALITAS LARVA( $\%$ ) BASED ON VALUES TRANSFORMED TO Arcsine(Sqr(X/100))

\begin{tabular}{|c|c|c|c|c|}
\hline SV & $\mathrm{DF}$ & SS & MS & $\mathrm{F}$ \\
\hline \multicolumn{5}{|c|}{ 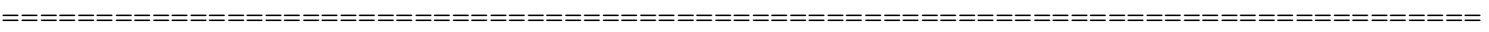 } \\
\hline PERLAKUAN (P) & 5 & 1244.804673 & 248.960935 & $62.86 \star \star$ \\
\hline ERROR & 18 & 71.289971 & 3.960554 & \\
\hline \multicolumn{5}{|c|}{-------------------------------------------------------------------------------} \\
\hline TOTAL & 23 & 1316.094645 & & \\
\hline
\end{tabular}

TABLE OF PERLAKUAN (P) MEANS FOR MORTALITAS LARVA (ㅇ) BASED ON ORIGINAL SCALE

(AVE. OVER 4 REPS)

\begin{tabular}{|c|c|c|}
\hline PERLAKUAN & MEANS & DIFFERENCE \\
\hline P1 & 20.0000 & $18.2500 \star \star$ \\
\hline P2 & 19.7500 & $18.0000 \star \star$ \\
\hline P3 & 17.5000 & $15.7500 \star \star$ \\
\hline P4 & 17.2500 & $15.5000 \star \star$ \\
\hline P5 (CONTROL) & 1.7500 & - \\
\hline P 6 & 20.0000 & $18.2500 \star \star$ \\
\hline MEAN & 16.0417 & \\
\hline
\end{tabular}

$\star \star=$ significant at $1 \%$ level

TABLE OF PERLAKUAN (P) MEANS FOR MORTALITAS LARVA (을 BASED ON TRANSFORMED SCALE

(AVE. OVER 4 REPS)

\begin{tabular}{|c|c|c|}
\hline PERLAKUAN & MEANS & DIFFERENCE \\
\hline---- & ------- & ---- \\
\hline P1 & 26.5650 & $20.0064 \star \star *$ \\
\hline P2 & 26.3842 & $19.8256 \star \star$ \\
\hline P3 & 24.7091 & $18.1505 \star \star$ \\
\hline P 4 & 24.5178 & $17.9592 \star \star$ \\
\hline P5 (CONTROL) & 6.5586 & - \\
\hline P 6 & 26.5650 & $20.0064 \star \star \star$ \\
\hline-----1 & - - - - - - - & - \\
\hline MEAN & 22.5500 & \\
\hline
\end{tabular}

$\star \star=$ significant at $1 \%$ level 


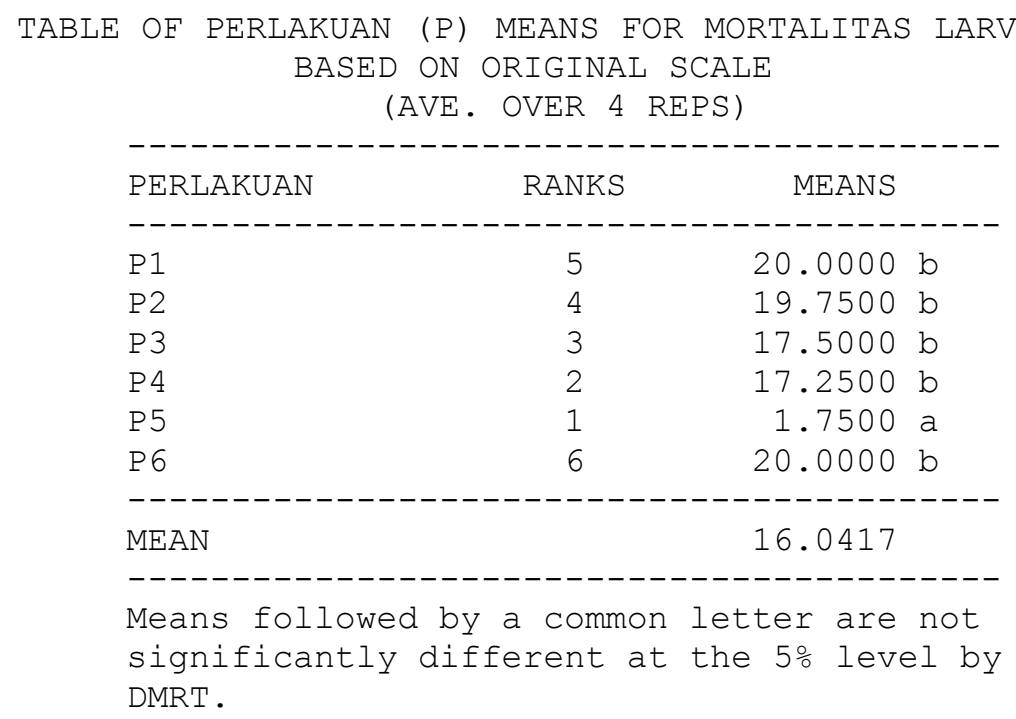

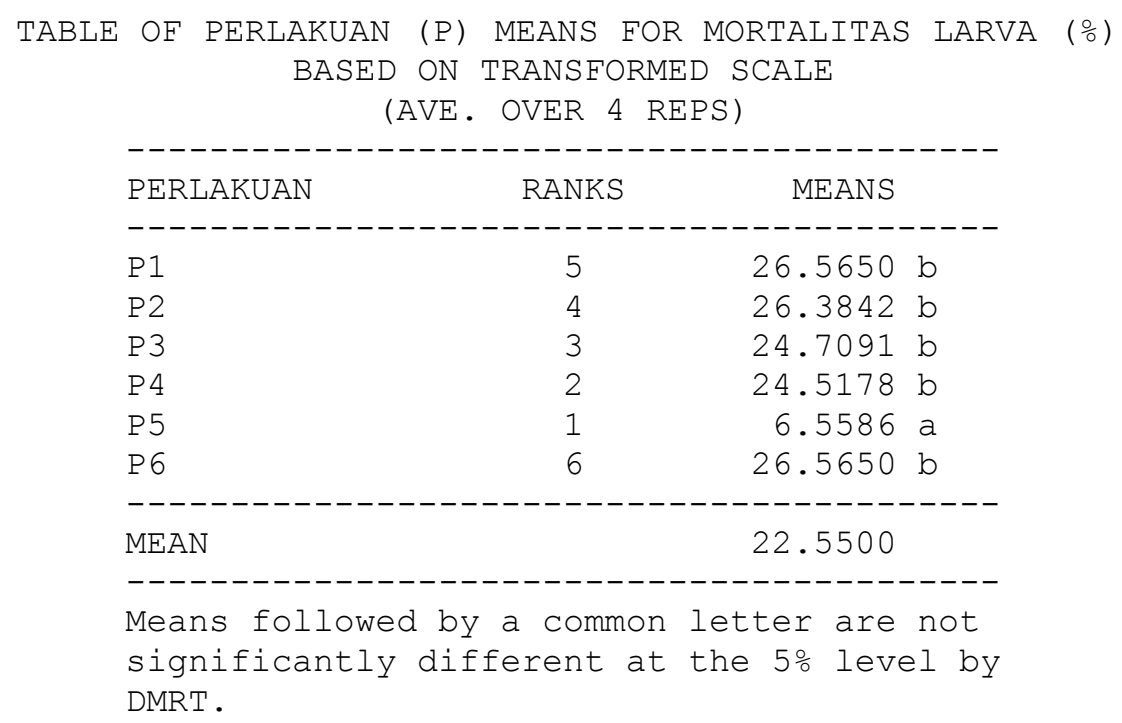

*** END OF ANALYSIS OF VARIANCE RUN *** 